accuracy of the rarity of onanism among them is not proven) is on a par with the statement frequently made that, owing to the same cause, cancer of the uterus is comparatively rare amongst Jewish women. It is the fallacy, too common in our profession, of arguing from one present knowledge of appendicitis an infinitely stronger case could be made out for removing the vermiform appendix in all children (male or female); but in this country surgeons have not yet proposed such a or female); but in this country surgeons have not yet proposed such a
drastic course as a preventive of subsequent appendicitis (a condition in its immediate dangers and remote effects very much more serious than masturbation) Circumcision as a preventive measure of masturbation was several years ago suggested and carried out by certain purgeons; the results were anything but satisfactory, and I believe the ditions, is a thing of the past. The truth is, in 99 out of roocases the habit arises either as the result of some mental deficiency or lowered moral two filthy bnys will corrupt a whole school. The habit is to be prevented by the avoidance of low companions, by the fostering of a high moral - tone at our public schonis, by encouraging everything (open-air exercise, unstimulating food and literature) to keep up bodily vigour, and, teacher as to the laws of physiology. It is by such means, rather than hy the absurd idea of circumcising every infant, that the habit of mastubation will be eradicated.

\section{A MODERN LIBRAR}

Rústicus desires to have recommended a list of books on different subjects for the purpose of bringing his medical library up to date.

*** The following might prove suitable for his purpose: Textbook of Medicine, by G. A. Gibson, in two volumes (London and Edinburgh : Young J. Pentland, rgor, 25s.); A Manual of the Practice of Medicine, by Frederick Taylor, Sixth Edition (London : J. and A. Churchill, rgor, 16s.), or The Principles and Practice of Medicine, by W. Osler, Third Edition (Edinburgh and London: Young J. Pentland, r898, 24s.); Manual of Midwifery, by W. E. Fothergill, Second Edition (Edinburgh: W. F. Clay, 19:0, 9s.); and Diseases of Women, by G. E. Herman, M.B., F.R.C.P., (London: Cassell and Co., 1898, 25S.); An Introduction to Pathology and Morbid Anatomy, by T. H. Green, Ninth Edicion revised by H. M. Murray (London: Henry Renshaw, 1900, 21s.), or $A$ Manual of Pathology, by J. Coats, Fourth Edition, revised by $\mathbf{L}$. $\mathbf{R}$. Sutherland (London : Longmans, Green and Co.. 1900, 31s. 6d.); Guide to the Clinical Examination and Treatment of Sick Children, by J. Thomson (Edinburgh: W. F. Clay, r898, 9s.), or Medical Diseases of Infancy and Childhood, by D. Williams, M.D. (London : Cassell and Co., 1898, ros. 6d.); The Diseases of Children, Medical and Surgical, by $\mathbf{H}$. Ashby and G. A. Wright, Fourth Edition (London : Longmans, Green and Co., r899, 25s.); The Surgical Diseases of Children, by E. Owen, Third Edition (London: Cassell and Co., 1897, 21S.), or Surgical Diseases of Children, by D'A. Power (London: H. K. Lewis, 1895, ros. 6d.) ; Tropical Diseases, by P. Manson, Second Edition (London: Cassell and Co., rgoo, ros. 6d.); Textbook of Forensic Medicine and Toxicology, bylA. P. Luff, M.D., in two volume (London : Longmans, Green, and Co., $1895,24 \mathrm{~S}$.$) , or A$ Treatise on Medical Jurisprudence, by G. V. Poore, M.D., F.R.C.P. (London : John Murray, rgor, 12S.): Textbook of Medical Treatment, by Nestor Tirard (London: J. and A. Churchill, r9oo, r5s.), and $A$ Texibook of Pharmacology and Therapeutics, by A. R. Cushny. M.A., M.D. Second Edition (London: Rebman Limited, roor, r7s. 6d.) An American Textbook of Genito-Urinary Discases, Syphilis, and Diseases of the Skin, by L. B. Bangs, M.D., and W. A. Hardaway, A.M., M.D., in two volumes (London : Rebman, Limited, 1898, 42S.) ; Disenses of the Ear Nose, and Throat, and their Accessory Cavities, by S. S. Bishop, M.D. D.C.L., LL.D., second edition (Philadelphia and London : F. A. Davis Co., 1898, 168.), or Diseases of the Nose and Throat, by F. de Havilland Hall and $H$. Tilley, second edition (London: H. K. Lewis, rgor, ros. 6d.), or Diseases of the Upper Respiratory Tract, the Nose, Pharynx, and Larymx, by P. W. Williams, fourth edition (Bristol : J. Wright and Co., rgor, 178. 6d.) Deformities, by A. H. Tubby, M.S., F.R.C.S. (London : Macmillan and Co. $\times 896,178$.$) , or Orthopcedic Surgery, by C. B. Keetley, F.R.C.S. (London:$ Smith, Elder and Co., rgoo, r6s.); Diseases of the Nervous Sytem, by $\mathbf{H}$ Oppenheim, M.D., authorised translation from the second German edition by E. E. Mayer (London : J. B. Lippincott Co., rgor, 21s.).

\section{HETTERs, NOTES, Ete.}

ERRATUM.-In the notes on Cyprus fever by Dr. G. A. Williamson (BRITISH MEDICAL JoURNAL, September 14th, p. 686, col. 2, line 32) for "Delhi

Tife Light TREATMENT OF LUPUS : a CoRrection.

Tik remarks of Dr. G. B. Batten on this subject in the BRITISH MEDICA JoU RNAL of September 28 th, p. 854 , col. , last line et seq., should read as follows and not as printed : "One should never use a tubewith a blu cloud in front of the anticathode, and seldom one with the blue cloud behind the anticathode. A soft tube gave similar or even quicker
results, but w is more dangerous, that was, more likely to cause dermatitis results, butw is more,

MUjic Practice an NeURotic Girls

DR. HAMrL -ON HALL (Fo dcombe, Tu b id se Wells) writez: It is difficult to agree with "P. B. G." tha' an ho:r's piano prac ice dily is permis- sible in the case of a neurotic girl, and it is still more difficult to agree with Dr F. D Kirny that the strength of the forearm is a factor for consideration. Several years experience of neurotic children result in a very strong opinion that the finger movements of piano practice make a very large and exhausting demand upon the brain energy, what ever that may be. "C. P." would do well to forbid the piano altogether for a protracted interval of time, and if he can get the neurotic manifestations remedied in the interval he will be able to observe their return when the practising is resumed. Singing is infinitely less exacting in this connection, but the neurotic girl can easily have too much of that. In a like case where one hour is required I have it

\section{LETTERS, OOMMUNIOATIONS, ETC.. have been received from}

A Another General Practitioner; Absenteo; Miss M. B. Andrews, M.B., Kirkwall; nxious; Dr. F. W. Andrews, London; A.M.S. Dr. P. Ashworth, Southport; A. T. W.; Antiquack; Antibosh; Dr. T. O. Askin, Woodbridge. B Mr. O. .. G. Bateman, Walbent, Manchester; Dr. J. W. Byers, Belfast; Dr. G. B. Batten, London; Mr. L. O. baker, Southsea ; Dr. J. Barr, Liverpool; Mrs. W. Bruce, London; Dr. C. E. Beevor, London. C Dr. E. M. Corner, London; O. P. Crouch, M.B., Weston-super-Mare; Captain R.A.M.C.: A. Cox, M.B., Gateshead; Mr. W. R. Oooper, Southsea; Dr. H. Campbell, London; Civil Surgeon; Mrs. Crossley, Buckhurst Hill; Mr. A. Cooper, London. M D. S. Q.; Mr. H. G.F. Dawson, Birkenhead: Dissatisfied; Dr. T. Dutton, London; Mr. W. F. Dearden, Manchester; Distracted. E H. P. Elliot, M.B., Morden, Manitoha; Edinburgh; Electrician; J. Erskine, M. B., Glasgow. T Mrs. Farquharson, Meigle. G Mr. J. W. Gill. Liskeard; Mr. H. C.'T. Gardner, London; J. Grimshaw, M B., Aldershot; Dr. J. G. Glover, London; G. P.; Giedencooft. I Mr. R. J. D. Hepple.
Harton; Dr. J. B. Hellier, Leeds : Mr. H. N. Hardy, London; Mr. A. B. Hicks, London; Harton; Dr. J. B. Hellier, Leeds : Mr. H. N. Hardy, London; Mr. A. B. Hicks, London; Dr. F. J. Hicks, Killadeas ; Dr. G. W. Hill, London. J Mr. H. O. Jones, London; Dr.
G. L. Johnson, London ; Justice. I J. Lloyd-Roberts, M.B., Colwyn Bay ; Mr. O. J. R. Lawday, Dartmouth; London School of Medicine for Women, Secretary of, London; Lupus. M Mr. W. J. Midelton, Bournemouth; M.; H. Mason, M.B., Leamington; Dr. R. U. Moftat, O.M.G., Sevenoaks; Mr. J. McKay, London; Mr. T. I. Mille, Easing wold; Mr. A. MacLean, London; Mr. R. A. Mossman, St. Leonard's.on-Ses; Mr. O. D. Marshall, London; Myosin-Albumin Meat Extract Company, Manager of, London M.B.Lond. N Miss K. Newell, London. O Dr. L. J. H. Oldmeadow, London. P Paychic; Mr. C. B. Pasley, Cahir; Mr. E. O. Papillon, London; P. P.; Problem; Pleximeter. Raven, Broadstairs. D. Redmond. Manchester; Dr. J. S. R. Russell, London; Mr. T. on-Sea; Mr. . Saywell, Nottingham; Mr. P. Stewart, Dublin; Mr. W. M. Storrar, Belfast; B. Strachan, M. B., Sunderland; Dr. J. H. Swanton, London; Dr. H. Smith, London; Mr. W. Stuart.Low, London; Mr. T. G. Scott, London. T Dr. W. J. Tyson,
Polkestone; T. S. Tuke, M.B., London; Mr. J. W. Taylor, Birmingham ; J. H. Targett,
M.B., London; P. E. Turner, M.B., Nagercoil. V Vaccina. W W. B.; Dr. D. Walsh, M. B., London; P. E. Turner, M.B., Nagercoil. v Vaccina. W W. B.; Dr. D. Walsh,
London; Mr. R. Walker. Clovelly; Dr. G. A. Williamson, Larnaca; Dr. A. Mco. Weir, London; Mr. R. Walker. Clovelly; Dr. G. A. Williamson, Larnaca; Dr. A. McO. Weir,
Liverpool; Mr. W. H. Wright. Derby; Wigan Medical Soeiety, Secretary of, Wigan; Liverpool; Mr. W. H. Wright, Derby; Wigan Medical Societ.y, Secretar
Mr. O. F. Wightman, London; J. R. Wortabet, M.B., Oambridge: Mr. Le G. Wursley, London; W.M. H.; Waverley; Dr. W. E. Wynter, London. Y York ; Dr. M.

BOOKS, ETc., RECEIVED.

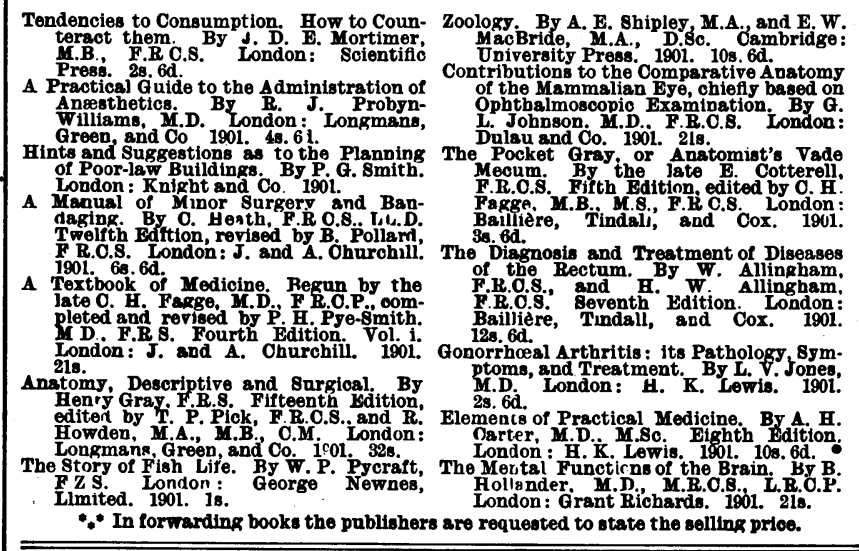

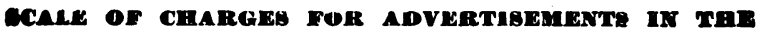
ERITIBH MEDICAI JOURNAL.

\begin{tabular}{|c|c|c|c|c|}
\hline $\begin{array}{l}\text { Eight lines and under } \\
\text { Each additional line ... }\end{array}$ & $\ldots$ & $\ldots$ & $\ldots$ & $\begin{array}{rl}60 & 4 \\
0 & 0\end{array}$ \\
\hline A whole column & ... & $\ldots$ & $\ldots$ & 127 \\
\hline A page & ... & ... & ... & 55 \\
\hline
\end{tabular}

Adrertisements should be delivered, addressed to the Manager, at the Office, not later than first post on Wednesday morning preceding publicaton; and if not paid for at the time, should be accompanied by a reference. Post-Office Ordors should be made payable to the British Medical Association at the General Post-Office, London. Small amounts may be paid in postage-stamps.

N.B.-It is against the rules of the Post Office to receive letters at Postes Restantes addressed either in initials or numbers. 